\title{
PREVALENCE OF SUBCLINICAL MASTITIS IN LACTATING COWS AND EFFICACY OF INTRAMAMMARY INFUSION THERAPY
}

\author{
T. K. Tripura ${ }^{1}$, S. C. Sarker ${ }^{2}$, S. K. Roy ${ }^{3}$, M. S. Parvin, R. R. Sarker, A. K. M. A. Rahman and M. T. Islam* \\ Department of Medicine, Faculty of Veterinary Science, Bangladesh Agricultural University \\ Mymensingh-2202, Bangladesh
}

\begin{abstract}
The aim of the study was to estimate the prevalence of subclinical mastitis (SCM) in lactating cows of Mymensingh and Lakshmipur sadar upazilas and to evaluate the efficacy of intramammary infusion in subclinical mastitis affected cows. A cross-sectional study was carried out on 78 smallholder dairy farms using a pretested questionnaire to collect data from June 2011 to May 2012. Milk samples from 139 lactating cows were screened for SCM by California Mastitis Test. A total of 72 cows was found positive for SCM and treated with the Neomastipra-JR5 ${ }^{\circledR}$ intramammary infusion tube (Hipra, Spain). The overall prevalence of subclinical mastitis in lactating cows was $51.8 \%$, of which $51.4 \%$ at Mymensingh sadar and $52.2 \%$ at Lakshmipur sadar upazilas. The prevalence of subclinical mastitis was significantly increased with age and parity of cows. In left hind quarter, the prevalence of subclinical mastitis was significantly higher (33.1\%) than those of other quarters. The efficacy of intramammary infusion with Neomastipra-JR $5^{\circledR}$ in lactating cows was $66.7 \%$.
\end{abstract}

Key words: Sub-clinical mastitis, lactating cows, California Mastitis Test, intramammary infusion

\section{INTRODUCTION}

Mastitis is an inflammatory condition of the mammary gland, characterized by the changes in the physical characteristics of the udder or milk (Nazifi et al., 2011). The subclinical mastitis (SCM) is more serious and is responsible for much greater loss to the dairy industry in Bangladesh (Kader et al., 2003). Subclinical mastitis is 15 to 40 times more prevalent than the clinical form, is of long duration and difficult to detect ((Almaw et al., 2008; George et al., 2008; Sarker et al., 2013). In Bangladesh, the prevalence of SCM is recorded from 20 to $44 \%$ at cow level based on California Mastitis Test (CMT) (Rahman et al., 2009; Islam et al., 2010; Rabbani and Samad, 2010). The efficacy of antibiotic therapy for intramammary infections (IMIs) early in lactation is scarce and few, with the ones carried out reporting mixed results. The response to therapy with intramammary (IMM) cephapirin sodium on CMT positive quarters in lactating cows on cure rates and somatic cell count (Rosenberg et $a l ., 2002)$. It was determined that by the 4 -week post-calving evaluation, quarters treated with cephapirin sodium had significantly increased cure rates, and SCC were significantly reduced. Wallace et al. (2004) also randomly assigning cows with CMT-positive quarters to receive either IMM cephapirin sodium or no treatment, found that there was no difference in cure rates for IMM antibiotic-treated quarters for major pathogens compared to the untreated cows. However, there was an advantage for cure rates using antibiotics against environmental streptococcal infections. Quarters with streptococci infections were 3.5 times more likely to cure if treated with cephapirin sodium. A field study has revealed that IMM antibiotic therapy was beneficial for Gram-positive organisms and coagulase-negative staphylococci, but ineffective for Gram-negative organism (Roberson et al., 2004), because Gram-negative bacteria tend to have a more complex layering in their cell wall structure (Beveridge, 1999). In a clinical trial in three Californian dairies, bacteriologic cure assessed at 4 and 20 days after treatment with amoxicillin, cephapirin, or oxytocin (no antibacterial) did not differ for mild clinical mastitis cases caused by any pathogen, although antibacterial treatment resulted in better clinical cure rates for cases caused by pathogens other than streptococci and coliforms (Guterbock et al., 1993). Proper milking procedure and hygiene may be the easiest and most economic way to control IMI (Hutton et al., 1990).

Present Address: ${ }^{1}$ Veterinary Surgeon, District Veterinary Hospital, Lakshmipur, Bangladesh ${ }^{2}$ Veterinary Surgeon, Upazila Livestock Office, Kaharol, Dinajpur, Bangladesh ${ }^{3}$ Veterinary Surgeon, Upazila Livestock Office, Patgram, Lalmonirhat

*Corresponding e-mail address: taohid.bau@gmail.com

Copyright (C) 2014 Bangladesh Society for Veterinary Medicine

All rights reserved 0289/2014 


\section{T. K. Tripura and others}

Teat and udder skin should be healthy before milking and free of sores, wounds, or chapping where S. aureus could colonize the teat end and surrounding skin (Fox and Norell, 1994). Cleanliness at milking time is also important. Minimal use of water and premilking teat antisepsis may reduce new IMI. Additionally, the advent of post milking teat antisepsis has been important in contributing to decreasing contagious IMI. When teats were dipped after milking and cows were treated with penicillin-dihydrostreptomycin at dry-off, IMI caused by major mastitis pathogens decreased by $75 \%$ and $45 \%$, respectively (Natzke et al., 1972; Oliver and Mitchell, 1984). Post-dipping alone has been estimated to decrease the rate of new IMI by 50\% (Nickerson and Boddie, 1997).

Antimicrobials are the most important tool in SCM control programs in cows. But there are not properly known by dairy farmers to infuse of intramammary antibiotics in SCM affected lactating cows. However, the reports on the efficacy of intramammary infusion in lactating cows are very limited (Siddiquee et al., 2013) and the information on the prevalence of SCM in the area is lacking or very less (Rahman et al., 2009; Rabbani and Samad, 2010; Rahman et al., 2010; Islam et al., 2011; Sarker et al., 2013). Therefore, the objectives of this study were to estimate the prevalence of subclinical mastitis in lactating cows using (CMT) and to evaluate the efficacy of intramammary infusion against SCM in lactating dairy cows.

\section{MATERIALS AND METHODS \\ Study sites and duration}

The study was carried out on 78 smallholder dairy farms (at least two lactating cows must be present in the farm) from 6 villages of Mymensingh Sadar upazila $(n=42)$ and 9 villages of Lakshmipur Sadar upazila $(n=$ 36). These farms were registered under Seed Bull Production Project of the Department of Genetics \& Animal Breeding, Bangladesh Agricultural University, Mymensingh. A total of 139 lactating cows, 72 from Mymensingh sadar and 67 from Lakshmipur sadar upazilas were included in this study. The cows were aged between 5 to 12 years, at different lactation stages, parity and level of milk production. The study work was conducted during the period from June 2011 to May 2012.

\section{Study design and data collection}

A cross-sectional study was carried out by using a pretested questionnaire to collect cow and farm level data. The animal level variables were age, pregnancy, parity, milk yield, lactation stage, stimulation of milking and history of previous clinical mastitis. Data were collected by interviewing the owners as well as examining the cows in the farm. Cows with signs of clinical mastitis were excluded from the study.

\section{Collection of milk samples}

Milk samples were collected after antiseptic wash of teats with $70 \%$ ethanol and dried off by tissue paper. Two streams of milk were discarded and then $5 \mathrm{ml}$ of milk were taken aseptically into labeled sterilized test tubes with rubber cap at the time of morning milking.

\section{Detection of subclinical mastitis}

Immediately after collection, the milk samples were subjected to CMT by using Leucocytest ${ }^{\circledR}$ (Synbiotics Corporation-2, France). A shallow half paddle having four cups was used. About $2 \mathrm{ml}$ milk was taken into the cup and $2 \mathrm{ml}$ reagent was added. Mixing was accomplished by gentle circular motion of the paddle in a horizontal plane for few seconds. The reaction developed almost immediately with milk containing a high concentration of somatic cells. The peak of reaction was obtained within 10 seconds. The results of CMT reaction were read immediately as per manufacturer's recommendation and were scored depending on the amount and thickness of gel formed.

\section{Intramammary infusion of subclinical mastitis (SCM) affected cows}

All the SCM affected cows $(n=72)$ received intramammary infusion with Neomastipra-JR5 (Benzylpnicillin procaine $100000 \mathrm{IU}$; Dihydrostreptomycin sulphate $62.4 \mathrm{mg}$; Neomycin sulphate $36 \mathrm{mg}$; Polymyxin B sulphate 50000 IU; Sulphadimidine sodium $250 \mathrm{mg}$; Sulphathiazole $250 \mathrm{mg}$; Hydrocortisone $20 \mathrm{mg}$, Hipra, Spain) at a dose of one syringe per affected quarter per cow twice daily after each morning and evening milking for 3 days. 
Prior to infusion, the affected quarter was thoroughly milked out by hand and the teat end was cleaned using a cotton swab soaked with $70 \%$ alcohol. After 15 days of last dosing, milk samples were collected and tested for CMT.

\section{Statistical analysis}

Data were entered into Microsoft Excel 2003 and transferred to STATA®, version 2012 (Stata Corporation, Texas, USA) for analysis. The overall prevalence of SCM and its distribution in different categories of variables and their exact binomial $95 \%$ confidence intervals were calculated. Simple bivariable associations of independent variables with SCM were investigated by $\chi 2$ test.

\section{RESULTS AND DISCUSSION}

\section{Prevalence of subclinical mastitis}

The overall prevalence of SCM in lactating cows was 51.8\%. The prevalence of SCM in Mymensingh sadar and Lakshmipur sadar was $51.4 \%$ and $52.2 \%$, respectively and there was no significant difference in the prevalence between two upazilas (Table 1).

The reported prevalence of SCM varied from $15.8 \%$ to $53.1 \%$ in crossbred cows in Bangladesh (Prodhan et al., 1996; Kader et al., 2002; Rahman et al., 2009; Rabbani and Samad, 2010; Rahman et al., 2010). These variations of prevalence rates of SCM might be due to difference of breed, management systems and test used for screening of milk samples.

Table 1. Prevalence of subclinical mastitis in lactating cows based on California Mastitis Test

\begin{tabular}{|c|c|c|c|c|c|}
\hline Location & $\begin{array}{l}\text { No. of cows } \\
\text { tested }\end{array}$ & $\begin{array}{l}\text { No. of positive } \\
\text { cows }\end{array}$ & Prevalence $(\%)$ & $\begin{array}{l}95 \% \text { confidence } \\
\text { interval }\end{array}$ & $\mathrm{p}$-value \\
\hline Mymensingh & 72 & 37 & 51.4 & $39.3,63.3$ & \multirow{3}{*}{0.92} \\
\hline Lakshmipur & 67 & 35 & 52.2 & $39.6,64.5$ & \\
\hline Total & 139 & 72 & 51.8 & $43.2,60.3$ & \\
\hline
\end{tabular}

The highest prevalence of SCM was $69.6 \%$ in cow's age above 7 years (Table 2). The prevalence of SCM was significantly $(\mathrm{p}<0.001)$ increased with age of cows. This finding agree with Neelesh et al. (2012) who reported highest prevalence of SCM in lactating cows with advancement of age. This could be explained by the fact that the teat canal in older animals is more dilated or it remains partially open permanently due to years of repeated milking (Madut et al., 2009). This encourages the introduction of environmental and skin-associated microorganisms into the teat canal, leading to SCM in cows (Karimuribo et al., 2008).

In terms of parity, the prevalence of SCM was significantly $(\mathrm{p}<0.001)$ higher in cows of above second parity in comparison to $1^{\text {st }}$ parity (Table 2). This observation supports with the reports of Joshi and Gokhale (2006), Byarugaba et al. (2008) and Rabbani and Samad (2010). The increase in the number of parity is associated with the corresponding increase in the prevalence of SCM (Sudhan et al., 2005, Islam et al., 2010). The higher prevalence of SCM in cows with the parity may be explained by the fact that resistance of cows might have lowered with advancement of parity (Byarugaba et al., 2008).

The prevalence of SCM was highest $(54.1 \%)$ in cows having more than 10 liter of milk production (Table 2), which is consistent with the report of Islam et al. (2011) who reported increased prevalence of SCM (42.85\%) with the increased milk production. The prevalence of SCM was higher (60\%) in pregnant cows than the nonpregnant cows $(47.2 \%)$. However, there was no significant relationship between pregnancy of cows and SCM (Table 2).

The prevalence of SCM was the highest in cows having pendulous udder (61.4\%) and cylindrical teat (58.1\%) (Table 2). Pendulous type of udder is of bigger size and more likely to be injured than an udder held up closure to the body (Probric et al., 1989; Sarker et al., 2013). SCM has a strong association with pendulous udder and cylindrical shaped teats (Uddin et al., 2009). The prevalence of SCM varied with the type of milking stimulation. Milking when stimulated by mustard oil, the prevalence was insignificantly higher (66.6\%) than milking stimulation by calves $(50.8 \%)$ (Table 2$)$. 


\section{T. K. Tripura and others}

Table 2. Prevalence of subclinical mastitis in lactating cows based on age, parity, milk yield, pregnancy, udder type and teat type and ways of milking stimulation

\begin{tabular}{|c|c|c|c|c|c|c|}
\hline Variables & & $\begin{array}{l}\text { No. of cows } \\
\text { tested }\end{array}$ & $\begin{array}{l}\text { No. of } \\
\text { positive cows }\end{array}$ & Prevalence $(\%)$ & $\begin{array}{l}95 \% \\
\text { confidence } \\
\text { interval }\end{array}$ & p-value \\
\hline \multirow[t]{2}{*}{ Age (year) } & $3.5-7$ & 83 & 33 & 39.8 & $29.2,51.1$ & 0.001 \\
\hline & $>7$ & 56 & 39 & 69.6 & $55.9,81.2$ & \\
\hline \multirow[t]{2}{*}{ Parity } & $1-2$ & 69 & 26 & 37.7 & $26.3,50.2$ & 0.001 \\
\hline & $>2$ & 70 & 46 & 65.7 & $53.4,76.7$ & \\
\hline \multirow{3}{*}{$\begin{array}{l}\text { Milk yield } \\
\text { (litre) }\end{array}$} & $1-5$ & 15 & 6 & 40.0 & $16.3,67.7$ & 0.59 \\
\hline & $5-10$ & 39 & 20 & 51.3 & $34.8,67.6$ & \\
\hline & $>10$ & 85 & 46 & 54.1 & $42.9,64.9$ & \\
\hline \multirow[t]{2}{*}{ Pregnancy } & Absent & 89 & 42 & 47.2 & $36.5,58.1$ & 0.15 \\
\hline & Present & 50 & 30 & 60.0 & $45.2,73.6$ & \\
\hline \multirow[t]{2}{*}{ Udder type } & Round & 82 & 37 & 45.1 & $34.1,56.5$ & 0.06 \\
\hline & Pendulous & 57 & 35 & 61.4 & $47.6,74$ & \\
\hline \multirow[t]{2}{*}{ Teat type } & Conical & 77 & 36 & 46.8 & $35.3,58.5$ & 0.18 \\
\hline & Cylindrical & 62 & 36 & 58.1 & $44.8,70.5$ & \\
\hline \multirow{2}{*}{$\begin{array}{l}\text { Milking } \\
\text { stimulation }\end{array}$} & Calf & 130 & 66 & 50.8 & $41.9,59.6$ & 0.36 \\
\hline & Mustard oil & 9 & 6 & 66.6 & $29.9,92.5$ & \\
\hline
\end{tabular}

\section{Quarter-wise prevalence of subclinical mastitis in lactating cows}

Quarter-wise prevalence of SCM was $28.1 \%$ in Left Front (LF), 33.1\% in Left Hind (LH), 24.5\% in Right Front (RF), and $17.3 \%$ in Right Hind quarters by CMT (Table 3). The prevalence of SCM in LH quarter (33.1\%) was significantly higher than RH quarter. These findings are in agreement with Sudhan et al. (2005) who reported that the hind quarter was the most affected quarter. Sharma et al. (2007) also reported that single and hind quarter involvement was maximum in case of SCM. This could be explained by the fact that the hind quarters are more exposed to dung and urine (Chakrabarti, 2007).

Table 3. Quarter-wise prevalence of subclinical mastitis in lactating cows

\begin{tabular}{|lcccccc|}
\hline Quarters & $\begin{array}{c}\text { No. of } \\
\text { tested cows }\end{array}$ & \multicolumn{3}{c}{ CMT positive, No. (\%) } & $\begin{array}{c}\text { 95\% confidence } \\
\text { interval }\end{array}$ \\
\cline { 3 - 6 } & & $1+$ & $2+$ & $3+$ & Total & \\
\hline LF & 139 & $23(16.5)$ & $13(9.4)$ & $3(2.2)$ & $39(28.1)$ & $20.8,36.3$ \\
LH & 139 & $24(17.3)$ & $16(11.5)$ & $6(4.3)$ & $46(33.1)$ & $25.4,41.6^{* *}$ \\
RF & 139 & $24(17.3)$ & $8(5.8)$ & $2(1.4)$ & $34(24.5)$ & $17.6,32.5$ \\
RH & 139 & $15(10.8)$ & $6(4.3)$ & $3(2.2)$ & $24(17.3)$ & $11.4,24.6^{* *}$ \\
\hline Total & 556 & $86(15.5)$ & $43(7.7)$ & $14(2.5)$ & $143(25.7)$ & $22.1,29.6$ \\
\hline
\end{tabular}

LF = Left Front, $\mathrm{LH}=$ Left Hind, RF = Right Front and RH = Right Hind.

***ignificant at $\mathrm{p}<0.001$. 


\section{Efficacy of intramammary infusion in lactating cows}

The efficacy of intramammary infusion in the treatment of IMIs in lactating cows was $66.7 \%$ in this study. The efficacy was insignificantly higher at Mymensingh sadar upazila (70.2\%) than the Lakshmipur sadar upazila (62.9\%) (Table 4). The efficacy of intramammary infusion with penicillin G or penethamate has been shown similar result (McDougall et al., 2007). In this study, the efficacy of IMIs in lactating cows have shown better due to the proper infusion of IMM tube at every 12 hours interval on affected quarter and maintain udder hygienic environment. The combinations of penicillin and aminoglycosides have shown a better efficacy for SCM in cows (Taponen et al., 2002). Owens and Nickerson (2001) showed similar result with cephapirin benzathine, penicillin-streptomycin, penicillin-novobiocin and tilmicosin infused intramammary infection in lactating cows for SCM.

Table 4. Efficacy of intramammary infusion with Neomastipra-JR5 ${ }^{\circledR}$ in lactating cows affected with subclinical mastitis

\begin{tabular}{|lllll|}
\hline Area & $\begin{array}{l}\text { No. of SCM } \\
\text { affected cows } \\
\text { treated }\end{array}$ & $\begin{array}{l}\text { No. of cows recovered after } \\
\text { IMM infusion (CMT negative } \\
\text { cows) }\end{array}$ & $\begin{array}{l}\text { Percentage of } \\
\text { recovered cows }\end{array}$ & 95\% CI \\
\hline Mymensingh & 37 & 26 & $70.3 \%$ & $53.0,84.1$ \\
Lakshmipur & 35 & 22 & $62.9 \%$ & $44.9,78.5$ \\
\hline Total & 72 & 48 & $66.7 \%$ & $54.6,77.3$ \\
\hline
\end{tabular}

In conclusion, the overall prevalence of SCM in lactating cows of smallholder dairy farms from Mymensingh and Lakshmipur sadar upazila are found similar result. The higher prevalence was found advancement of age and parity. The prevalence was also high due to increasing of milk production of cows. Hind quarters were more susceptible to SCM than fore quarters in lactating cows. The efficacy of intramammary infections of SCM affected cows was found effective treatment with Neomastipra-JR5® intramammary infusion tube.

\section{REFERENCES}

1. Almaw G, Zerihun A and Asfaw Y ( 2008). Bovine mastitis and its association with selected risk factors in small holder dairy farms in and around Bahir Dar, Ethiopia. Tropical Animal Health and Production 40: 427-432.

2. Beveridge TJ (1999). Structures of gram-negative cell walls and their derived membrane vesicles. Journal Bacteriology 181: 4725-4733.

3. Byarugaba DK, Nakavuma JL, Vaarst M and Laker C (2008). Mastitis occurrence and constraints to mastitis control in smallholder dairy farming systems in Uganda. Livestock Research for Rural Development 20:1.

4. Chakrabarti A (2007). A textbook of Preventive Veterinary Medicine. $4^{\text {th }}$ edn., Kalyani Publishers, New Delhi, pp: 477.

5. Fox LK and Norell RJ (1994). Staphylococcus aureus colonization of teat skin as affected by postmilking teat treatment when exposed to cold and windy conditions. Journal of Dairy Science 77: 2281.

6. George LW, Divers TJ, Ducharme N and Welcome FL (2008). Rebhun's diseases of dairy cattle. Saunders Elsevier, St Louis, USA.

7. Guterbock WM, Van Eenennaam AL, Anderson RJ, Gardner IA, Cullor JS and Holmberg CA (1993). Efficacy of intramammary antibiotic therapy for treatment of clinical mastitis caused by environmental pathogens. Journal of Dairy Science 76: 3437-3444.

8. Hutton CT, Fox LK and Hancock DD (1990). Mastitis control practices: differences between herds with high and low somatic cell counts. Journal of Dairy Science 73: 1135.

9. Islam MA, Islam MZ, Islam MA, Rahman MS and Islam MT (2011). Prevalence of subclinical mastitis in dairy cows in selected areas of Bangladesh. Bangladesh Journal of Veterinary Medicine 9: 73-78.

10. Islam MA, Rahman AKMA, Rony SA and Islam MS (2010). Prevalence and risk factors of mastitis in lactating dairy cows at Baghabari milk shed area of Sirajganj. Bangladesh Journal of Veterinary Medicine 8(2): 157-162.

11. Joshi S and Gokhale S (2006). Status of mastitis as an emerging disease in improved and peri urban dairy farms in India. Annuals of the New York Academy of Sciences 1081: 74-83. 


\section{T. K. Tripura and others}

12. Kader MA, Samad MA and Saha S (2003). Influence of host level factors on prevalence and economics of subclinical mastitis in dairy cows in Bangladesh. Indian Journal of Dairy Science 56: 235-240.

13. Kader MA, Samad MA, Saha S and Taleb MA (2002). Prevalence and etiology of sub-clinical mastitis with antibiotic sensitivity to isolated organisms among milch cows in Bangladesh. Indian Journal of Dairy Science 55: 218-223.

14. Karimuribo ED, Fitzpatrick JL, Swai ES, Bell C, Bryant MJ, Ogden NH, Kambarage DM and French NP (2008). Prevalence of subclinical mastitis and associated risk factors in smallholder dairy cows in Tanzania. Veterinary Record 163(1): 16-21.

15. Madut NA, Godir AEA and El Jalil IM (2009). Host determinants of bovine mastitis in semi-intensive production system of Kharfoum State, Sudan. Journal of Cell and Animal Biology 3: 71-77.

16. McDougall S, Agnew KE and Cursons R (2007). Parenteral treatment of clinical mastitis with tylosin base or penethamate hydriodide in dairy cattle. Journal of Dairy Science 90: 779-789.

17. Natzke RP, Everett RW, Guthrie RS, Keown JF, Meek AM, Merrill WG, Roberts SJ and Schmidt GH (1972). Mastitis control program: effect on milk production. Journal of Dairy Science 55: 1256.

18. Nazifi S, Haghkhah M, Asadi Z, Ansari-Lari M, Tabandeh MR, Esmailnezhad Z and Aghamiri M (2011). Evaluation of sialic acid and acute phase proteins (haptoglobin and serum amyloid A) in clinical and subclinical bovine mastitis. Pakistan Veterinary Journal 31: 55-59.

19. Neelesh S, Gyu JR, Yeong HH, Tae YK, Hak Kyo Lee HK, Tai-Young H and Dong KJ (2012). Bovine Mastitis: An Asian Perspective. Asian Journal of Animal and Veterinary Advances 7: 454-476.

20. Nickerson SC and Boddie RL (1997). Mastitis prevention. Louisiana Agriculture 40: 24.

21. Oliver SP and Mitchell BA (1984). Prevalence of mastitis pathogens in herds participating in a mastitis control program. Journal of Dairy Science 67: 2436.

22. Owens WE and Nickerson SC (2001). Prevalence of mastitis in dairy heifers and effectiveness of antibiotic therapy. Journal of Dairy Science 84: 814-817.

23. Probric H, Pilipovic PM, Ailovic S and Kraier I (1989). Effect of various udder shapes on the occurrence of mastitis in cows. Veterinaria Sarajevo 38: 91-98.

24. Prodhan MAM, Kamal AHM, Mahabub-e-Elahi ATM (1996). Study on the prevalence of subclinical mastitis in cows of Bangladesh milk-shed area. Bangladesh Journal of Veterinary Medicine 30: 59-61.

25. Rabbani AFMG and Samad MA (2010). Host determinants based comparative prevalence of subclinical mastitis in lactating Holstein-Friesian cross cows and red Chittagong cows in Bangladesh. Bangladesh Journal of Veterinary Medicine 8(1): 17-21.

26. Rahman MA, Bhuiyan MMU, Kamal MM and Shamsuddin M (2009). Prevalence and risk factors of mastitis in dairy cows. Bangladesh Veterinarian 26: 54-60.

27. Rahman MM, Islam MR, Uddin MB and Aktaruzzaman M (2010). Prevalence of subclinical mastitis in dairy cows reared in Sylhet district of Bangladesh. International Journal of Bio Research 1: 23-28.

28. Roberson JR, Warnick LD and Moore G (2004). Mild to moderate clinical mastitis Efficacy of intramammary amoxicillin, frequent milk-out, a combined intramammary amoxicillin, and frequent milk-out treatment versus no treatment. Journal of Dairy Science 87: 583-592.

29. Rosenberg JB, Love B and Patterson DL (2002). Bacterial cure and somatic cell count response of dairy cows with a positive California Mastitis Test at calving to therapy with cephapirin sodium. Veterinary Therapeutics 3: 381386.

30. Sarker SC, Parvin MS, Rahman AKMA and Islam MT (2013). Prevalence and risk factors of Subclinical Mastitis in Lactating dairy cows in north and south region of Bangladesh. Tropical Animal Health and Production 45: 11711176.

31. Sharma N, Maiti SK and Sharma KK (2007). Prevalence, etiology and antibiogram of microorganisms associated with sub-clinical mastitis in buffaloes in Durg, Chhattisgarh State (India). International Journal of Dairy Science 2(2): 145-151.

32. Siddiquee NU, Tripura TK, Islam MT, Bhuiyan SA, Rahman AKMA and Bhuiyan AKFH (2013). Prevalence of sub-clinical mastitis in high yielding crossbred cows using draminski mastitis detector. Bangladesh Journal of Veterinary Medicine 11 (1): 37-41.

33. Sudhan NA, Singh R, Singh M and Soodan JS (2005). Studies on prevalence, etiology and diagnosis of sub clinical mastitis among cross bred cows. Indian Journal of Animal Research 39: 127-130.

34. Taponen S, Dredge K and Henriksson B (2002). Efficacy of intramammary treatment with procaine penicillin G vs. procaine penicillin plus neomycin in bovine clinical mastitis caused by penicillin-susceptible, gram-positive bacteria- a double blind field study. Journal of Veterinary Pharmacology and Therapeutics 26: 193-198. 
35. Uddin MA, Kamal MM and Haque ME (2009). Epidemiological study of udder and teat diseases in dairy cows. Bangladesh Journal of Veterinary Medicine 7: 332-340.

36. Wallace JA, Stipetic K, Schukken YH, Dingwell RT, Baillargeon P, Bacic G and Leslie KE (2004). An evaluation of a treatment protocol for intramammary infections in early postpartum dairy cows based on a positive California Mastitis Test. Bovine Practice 38: 72-78. 